\title{
One Job Town
}

Work, Belonging, and Betrayal in Northern Ontario

There's a pervasive sense of betrayal in areas scarred by mine, mill, and factory closures. Steven High's One Job Town delves into the long history of one such town located on Canada's resource periphery. Much like hundreds of other towns and cities across North America and Europe, Sturgeon Falls, Ontario, lost its primary source of industry, resulting in the displacement of workers and their families, when its century-old paper mill closed in 2002.

Through stories shared by mill workers, managers, and city officials, One Job Town takes us into the making of a culture of industrialism and the significance of industrial work and its loss for mill-working families. It approaches deindustrialization as a long-term economic, political, and cultural process, which did not simply begin and end with the closure of the local mill. Oral history and memory are at the heart of One Job Town, challenging us to rethink the relationship between the past and the present in what was formerly known as the industrialized world.

STEVEN HIGH is a professor of history at Concordia University and the author of Industrial Sunset: The Making of North America's Rust Belt, 1969-1984. 
This page intentionally left blank 

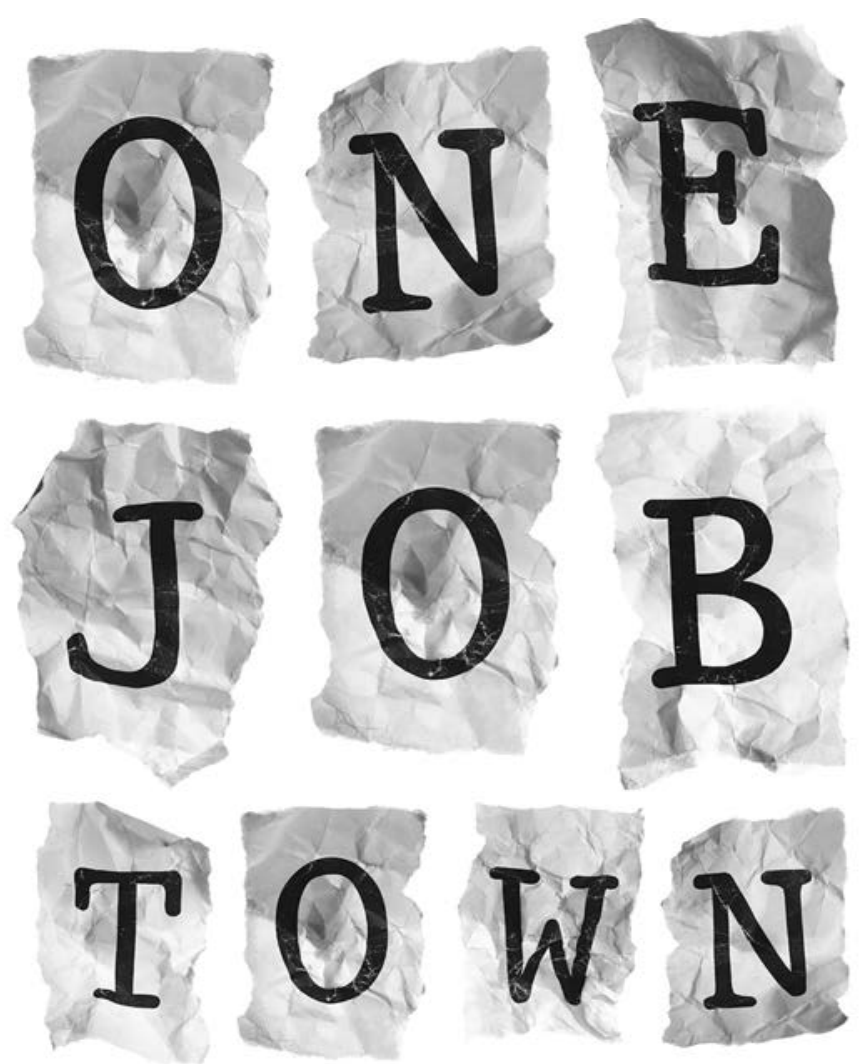

\section{W ORK, BELONGING, AN D BETRAYAL IN NORTHERN ONTARIO}

\section{Steven High}


(c) University of Toronto Press 2018

Toronto Buffalo London

utorontopress.com

Printed in Canada

ISBN 978-1-4426-4083-2 (cloth) ISBN 978-1-4426-1023-1 (paper)

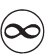

Printed on acid-free paper with vegetable-based inks.

Title page and chapter opening image: junjie/shutterstock

\section{Library and Archives Canada Cataloguing in Publication}

High, Steven C., author

One job town : work, belonging, and betrayal in Northern Ontario / Steven High.

Includes bibliographical references and index.

ISBN 978-1-4426-4083-2 (cloth). ISBN 978-1-4426-1023-1 (paper)

1. Paper mills - Ontario - Sturgeon Falls. 2. Mills and mill-work - Ontario -

Sturgeon Falls. 3. Paper industry - Ontario - Sturgeon Falls - Employees.

4. Deindustrialization - Ontario - Sturgeon Falls. 5. Sturgeon Falls (Ont.) -

Economic conditions - 20th century. 6. Sturgeon Falls (Ont.) -

Social conditions -20 th century. I. Title.

$$
\text { HD9834.C23S78 } 2018 \text { 338.7’67609713147 C2017-908046-6 }
$$

This book has been published with the help of a grant from the Federation for the Humanities and Social Sciences, through the Awards to Scholarly Publications Program, using funds provided by the Social Sciences and Humanities Research Council of Canada.

University of Toronto Press acknowledges the financial assistance to its publishing program of the Canada Council for the Arts and the Ontario Arts Council, an agency of the government of Ontario.

Canada Council Conseil des Arts for the Arts

\section{du Canada}

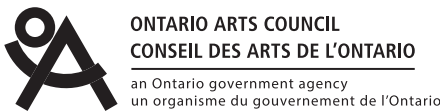

un organisme du gouvernement de l'ontario 
Class is something beneath your clothes, under your skin, in your reflexes, in your psyche, at the very core of your being.

- Annette Kuhn, historian 
This page intentionally left blank 